\title{
Environmental Benefit of Using Bagasse in Paper Production - A Case Study of LCA in Iran
}

\author{
Sotoodehnia Poopak and Amiri Roodan Reza
}

Additional information is available at the end of the chapter

http://dx.doi.org/10.5772/51553

\section{Introduction}

World paper and paperboard demand is expected to grow by about $2.1 \%$ till year 2020 and the growth will be fastest in Eastern Europe, Asia (except Japan) and Latin America [1]. There are two kinds of paper production: (a) using wood (virgin) as raw materials and (b) using non-virgin material like kanaf and bagasse [1]. There are several studies that applied LCA in pulp and paper products (Merrild et al.,2008; Murphy \& Power.,2007; Schmidt et al.,2007; Holmgren and Hening,2005; Dias,2007;Wiegard,2001; Fu et al.,2005 and Dias et al.,2002). In their research they discovered that energy and water consumption, Greenhouse Gases (GHG) and methane emissions, chlorine and raw materials used for non-virgin papers is less than virgin material. This study focused on LCA of non-virgin material (baggasse) in paper factory in Iran. The Pars Paper Factory is a government owned factory and is located in Southwest Iran and is $500 \mathrm{~m}$ from Hafttapeh Sugarcane factory. It was established in 1963 with a production capacity of 35,000 metric tonne per year. Nowadays, the production of this factory has reached 40,000 metric tonne per year. Hafttapeh Sugarcane factory was supplying bagasse to the paper factory. Water for this process is provided from the Dez River which is also near the factory. Source of energy for this factory is hydroelectricity and mazut. Mazut is a brownish-black petroleum fraction consisting largely of distillation residues from asphaltictype crude oils, with a relative density of about 0.95 .

\section{Problem statement}

Paper is made from plant fibers called cellulose, which are found in wood. Cellulose must be converted into pulp before being used to manufacture paper. To begin the papermaking process, recovered fiber is shredded and mixed with water to make pulp. The pulp is washed, refined and cleaned, then turned to slush in a beater. During the papermaking process emission can released into air and water and caused the air and water pollution. In 
additional, nowadays, by rapid economic development and population growth the demand for paper also increased in the world. More demand on paper needs more harvesting of woody materials. Unsustainable harvesting of wood can caused deforestation, climate change, etc. However, producing one metric tonne of paper from non virgin materials such as bagasse, kanaf and bamboo can save 17 trees,3.3 cubic meter $\left(\mathrm{m}^{3}\right)$ of landfill space, $360 \mathrm{~L}$ of water, $100 \mathrm{~L}$ of gasoline, 60 pounds of air pollutants, 10401 kilowatt of electricity [2,3]. On the other hand greenhouse gases (GHGs) such as carbon dioxide $\left(\mathrm{CO}_{2}\right)$, methane $\left(\mathrm{CH}_{4}\right)$ and nitrous oxide $\left(\mathrm{N}_{2} \mathrm{O}\right)$ are critical components of the earth's atmosphere. Without these gases, the earth would be in deep freeze. These gases act like a blanket, trapping heat around the earth and keep temperatures necessary for human life. However, anthropogenic activities such as fossil fuel burning, land clearing and deforestation can cause 'thickened the greenhouse blanket' which means can effected on climate changes. This paper was aimed to identify all impacts of paper making process in Iran, using LCA as a tool.

\section{Pars Paper Factory, Iran}

Pars Paper Factory is a government owned factory and is located in southwest of Iran. It is $1500 \mathrm{~km}$ from Tehran the capital city of Iran and 100 kilometers north of Ahvaz, 45 kilometers south of Andimeshk and 20 kilometers from Shush. This factory was near the Hafttapeh Sugarcane Factory which supplied the raw material for produce paper.

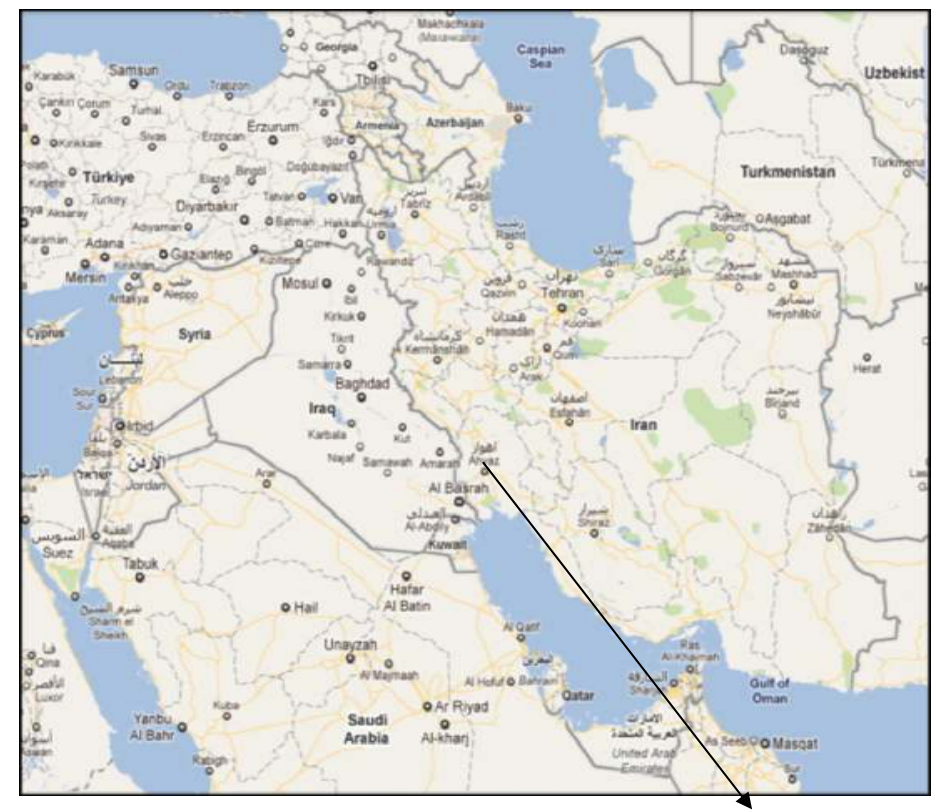

Pars paper factory

Figure 1. Location of Pars Paper Factory 
Pars Paper Factory was established in 1963 with 35,000 tonne paper production capacity per year. Nowadays, the production of this factory has reached 40,000 tonnes per year.

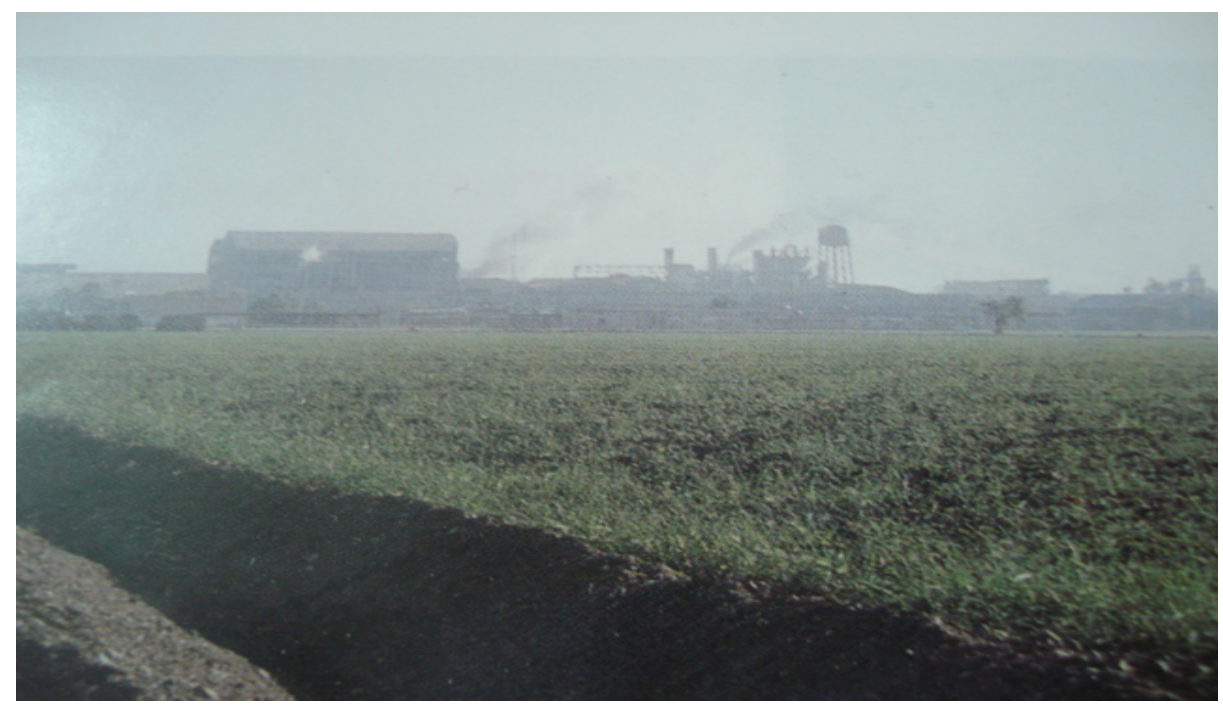

Figure 2. Pars Paper Factory

As shown in Figure 3, paper production process divides into three parts.

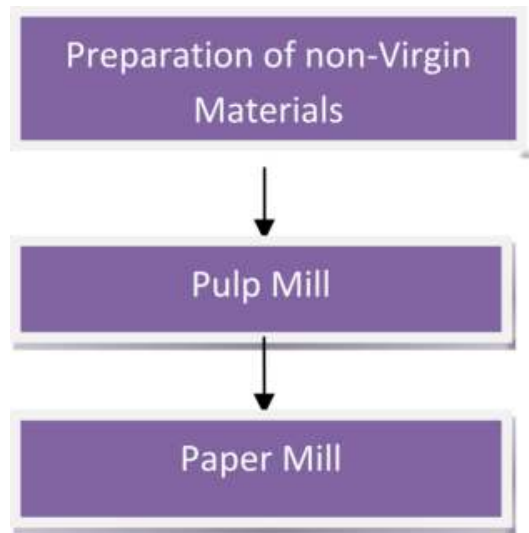

Figure 3. Paper Production Process

In preparation of non-virgin materials, bagasse was provided from sugarcane factory.

\subsection{Preparation of Bagasse}

Bagasse is the fibrous residue remaining after sugarcane is crashed to extract its juice and is currently used as a renewable resource in the manufacture of pulp and paper products and 
building materials. Using agricultural crops rather than wood has the added advantages of reducing deforestation. Due to the case with which Bagesse can be chemically pulped, Bagasse requires less bleaching chemicals than wood pulp to achieve a bright, white sheet of paper. Because of this reason there is less impacts of materials that used in the bleaching section such as Chlorine on the environment. The fibers are about $1.7 \mathrm{~mm}$ long and are well suited for tissue, corrugating medium, news print and writing paper. Bagasse contains 65$68 \%$ fibers, $25-30 \%$ pith, $2 \%$ sugar and $1-2 \%$ minerals. This factory brings the raw materials from sugarcane factory which is 500 meter from the paper factory .The raw materials send to paper factory through the pipe or conveyer belts. The energy that use for transported the Bagasse to the paper factory is water or air.

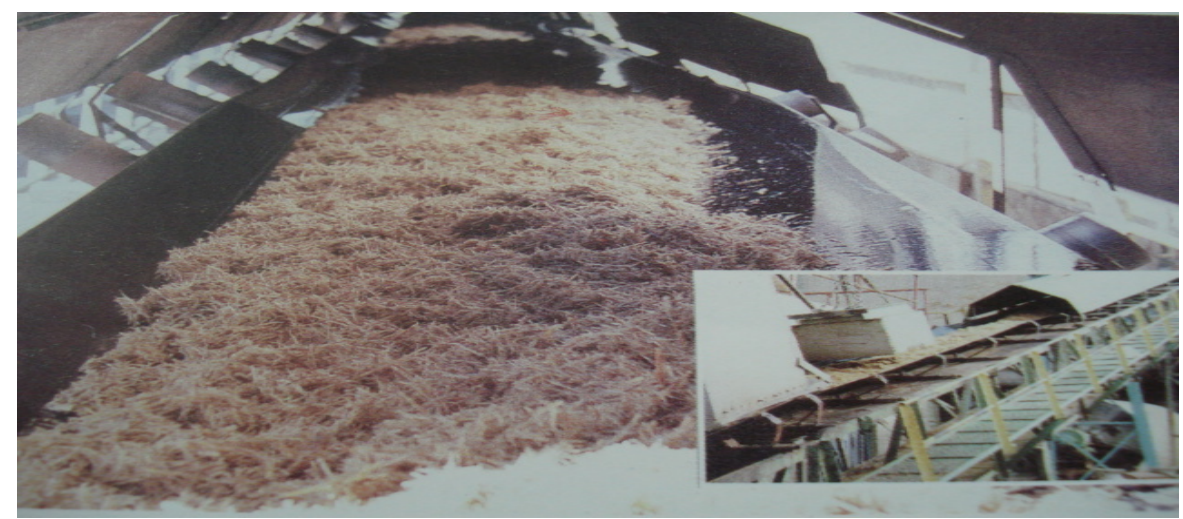

Figure 4. Transported the Bagasse through the conveyer belts from the sugarcane factory to the paper factory

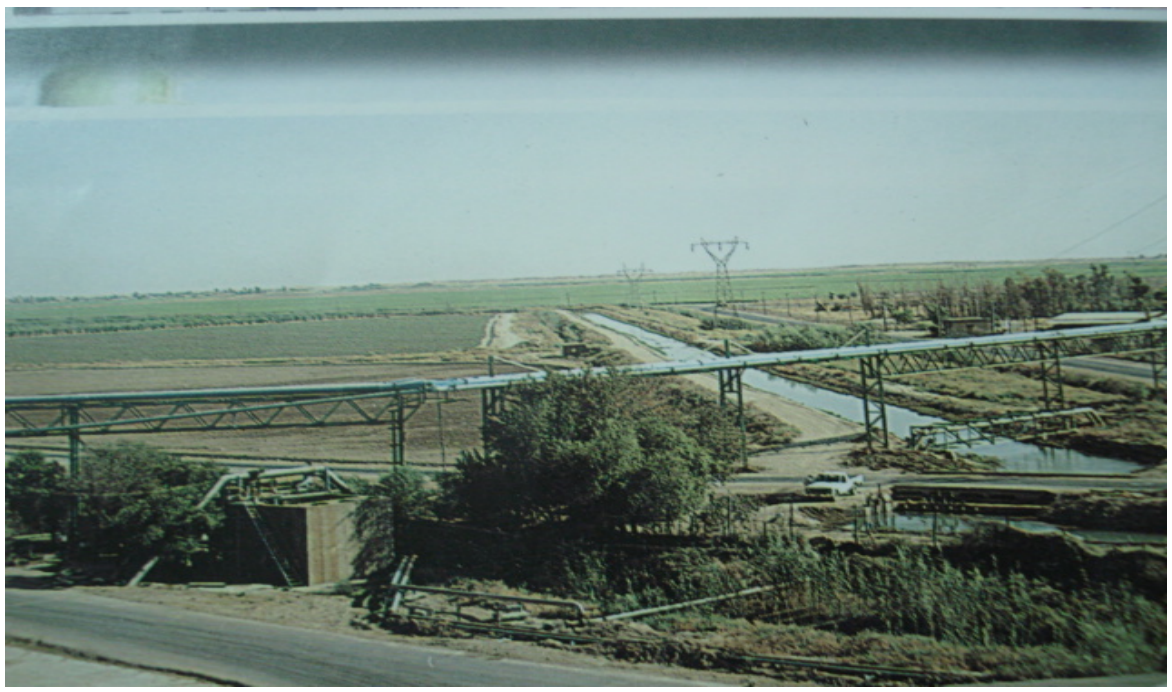

Figure 5. Transported the Bagasse through pipe from the sugarcane factory to the paper factory 
This is the section that separate fiber from the pith. This process called Depithing. The paper production is continuously for year because of that the factory store the Bagasse, therefore; the harvest of the sugarcane was on just 6 months and factory storage the Bagasse as it shown in figure 6 . The Bagasse has potential to fire so, it become wet to prevent the fire.

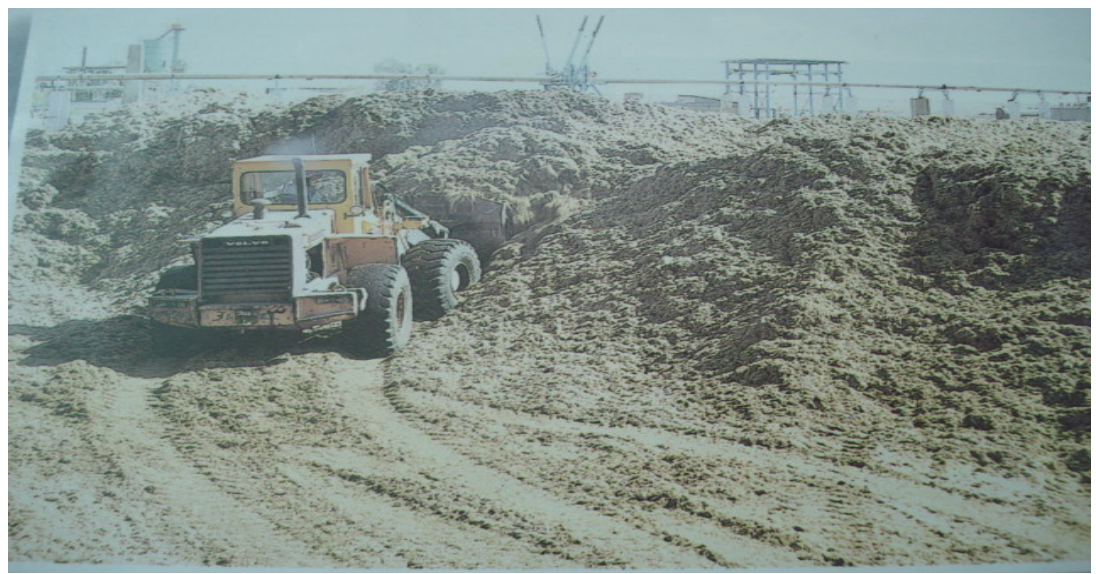

Figure 6. Bagasse Storage place in paper factory

The Bagasse before send to the Pulp mill part mixed with water and send to the

Bagasse Dewatering section to separate the pith and fibers.

\subsection{Pulp mill}

In this part there are five sections as follow: Cooking, Pulp washing, Pulp Screening \& Cleaning, Pulp Thickening and Bleaching.

\subsubsection{Cooking}

The fibers reduce the water by cooking in this section and the energy that use is steam. Approximately 10-15 minutes need to cook the fibers. This factory had 5 boilers however currently it just use 3 of them the reason is the rest is out of service.

\subsubsection{Pulp washing}

After cooking process the remainder called Pulp and it is in black color. The black pulp called Black Liquor, washed for three times to change the color.

\subsubsection{Pulp screening and cleaning}

This was the third section on the pulp mill process. In this stage remove all the sand and useless fibers. It was shown in Figure 9 as below. 


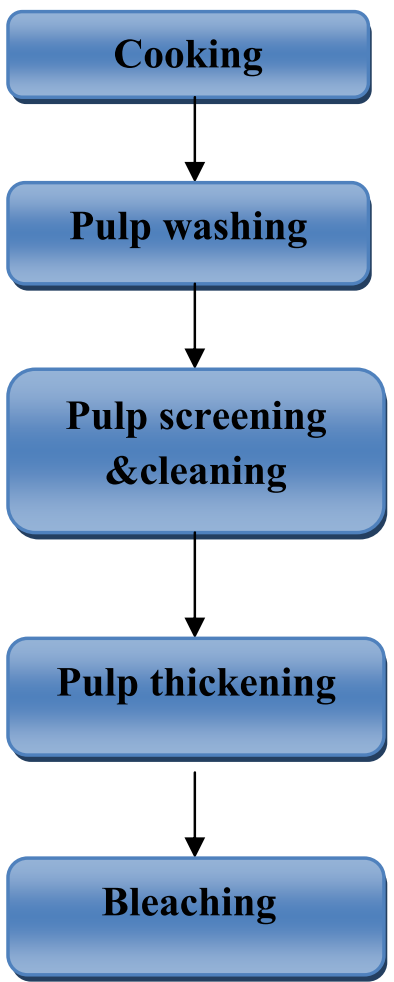

Figure 7. Pulp Mill Process

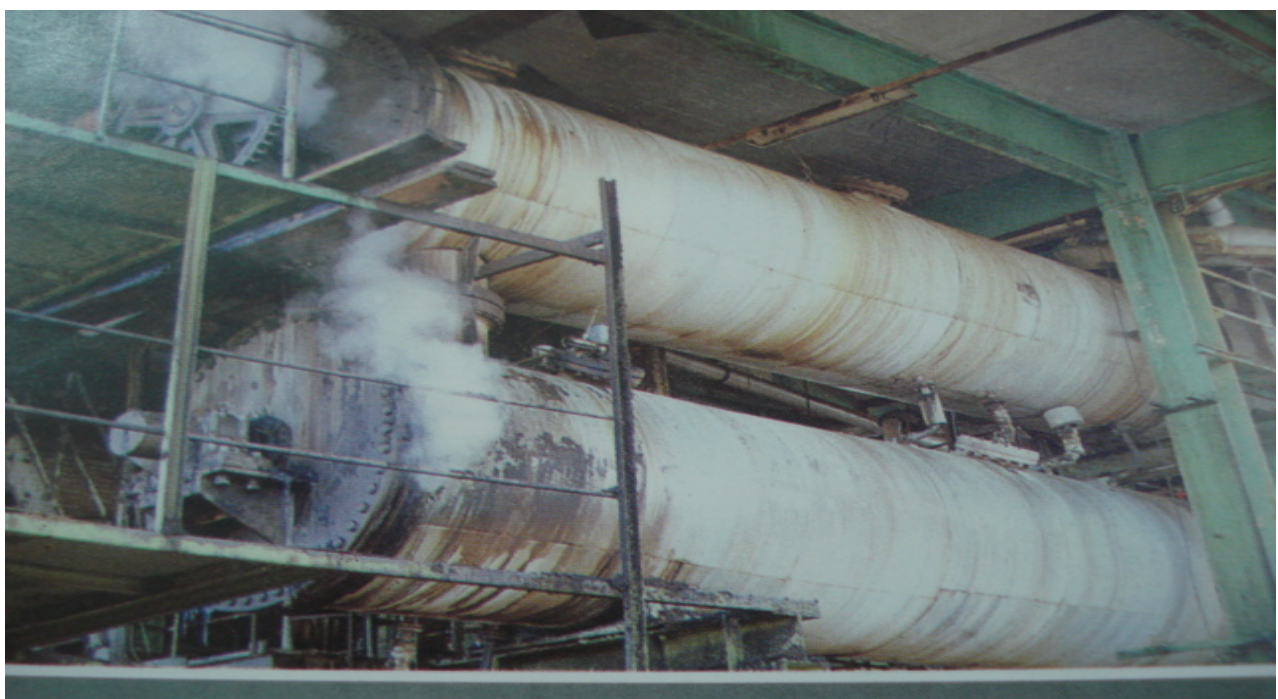

Figure 8. Cooking process on pulp mill in paper factory 


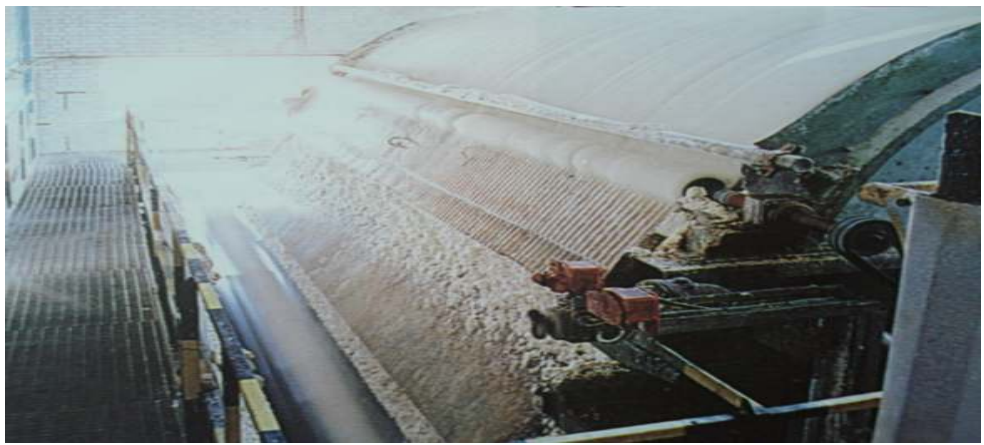

Figure 9. Pulp Screening \& Cleaning in paper factory

\subsubsection{Pulp thickening}

In this section, the pulp reduced the water around $12 \%$ in this stage.

\subsubsection{Bleaching}

The final section by using the $\mathrm{Cl}$ (Chlorine) gas and $\mathrm{NAOH}$ the Black Liquor changed color to the white color and the process done in three times.

\subsection{Paper mill}

This is the final part in the Pars Paper Factory. Final production is paper. Paper milling is the last process in producing paper. The pulp will go through several processes to finally become paper. The paper which is white in color is cut to A4 size. At this stage, the moisture in the paper is reduced to $55-60 \%$.

\section{Paper Mill Process}

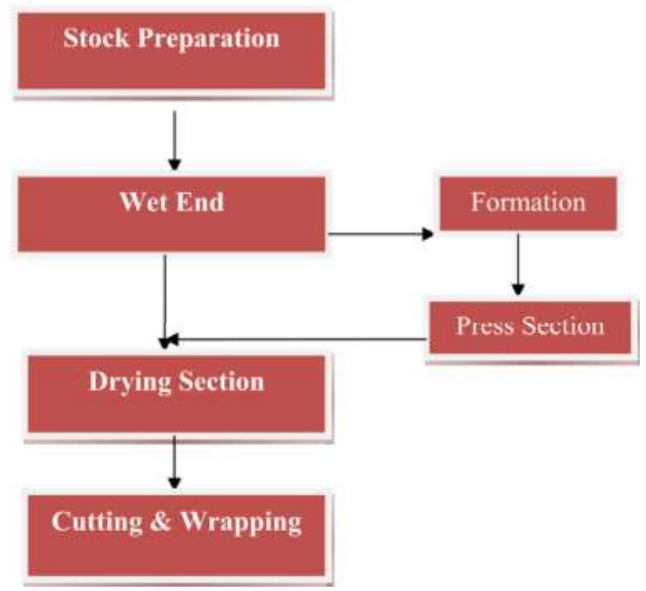

Figure 10. Paper Mill Process 


\subsubsection{Stock preparation}

Pulp is insufficient for making paper so, in this section adds materials such as Kraft to improve the pulp. In this stage additional material such as Kraft that use for this stage bought from Malaysia or Thailand.

\subsubsection{Wet end}

This section is very sensitive in Paper mill so, it is divided to the 2 subsection as follow:

\subsubsection{Formation}

\subsubsection{Press section}

After materials are added to the pulp it will go to the Flow Box and be spread on the mantle.

During this process the pulp gives up some water and it is then sent to the Drying Section.

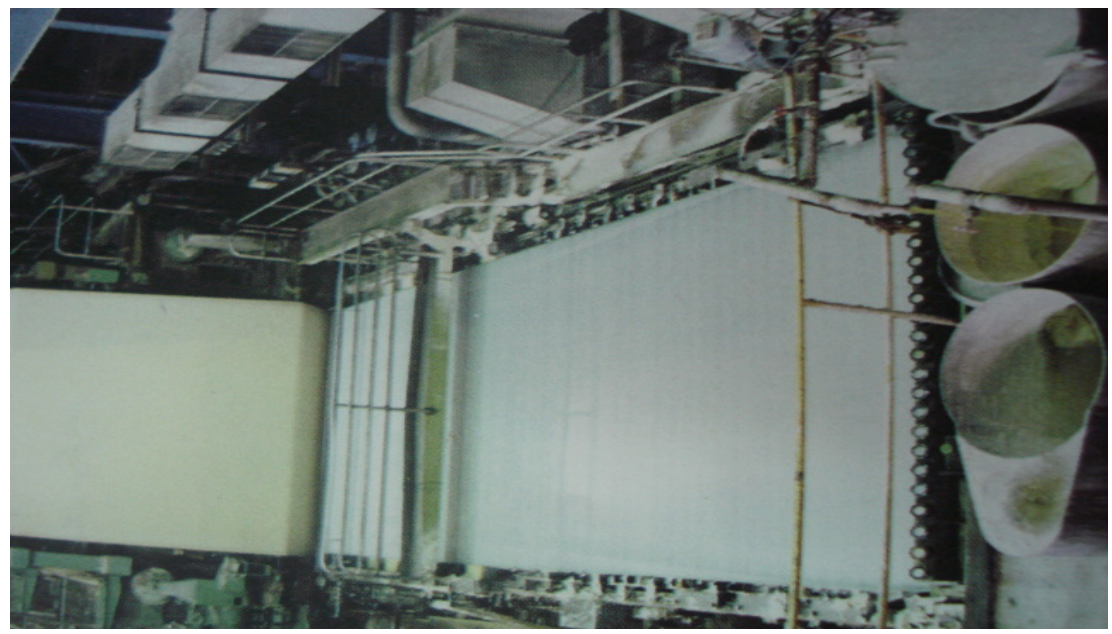

Figure 11. Wet End (Formation) Section

\subsubsection{Drying section}

Wet paper after Press Section with 55-60\% moisture passing from some cylinder .These cylinder heat with steam so, the paper will loss all the moisture. In this stage for improve the qualities of printing and surfacing of paper, it pass from the Callevdering (using iron) section and cover with starch. Inputs for this stage are corn starch and resin.

\subsubsection{Cutting and wrapping}

This is the final stage in the Paper mill .The cutting of the paper to size depends on the requirements of customer. 


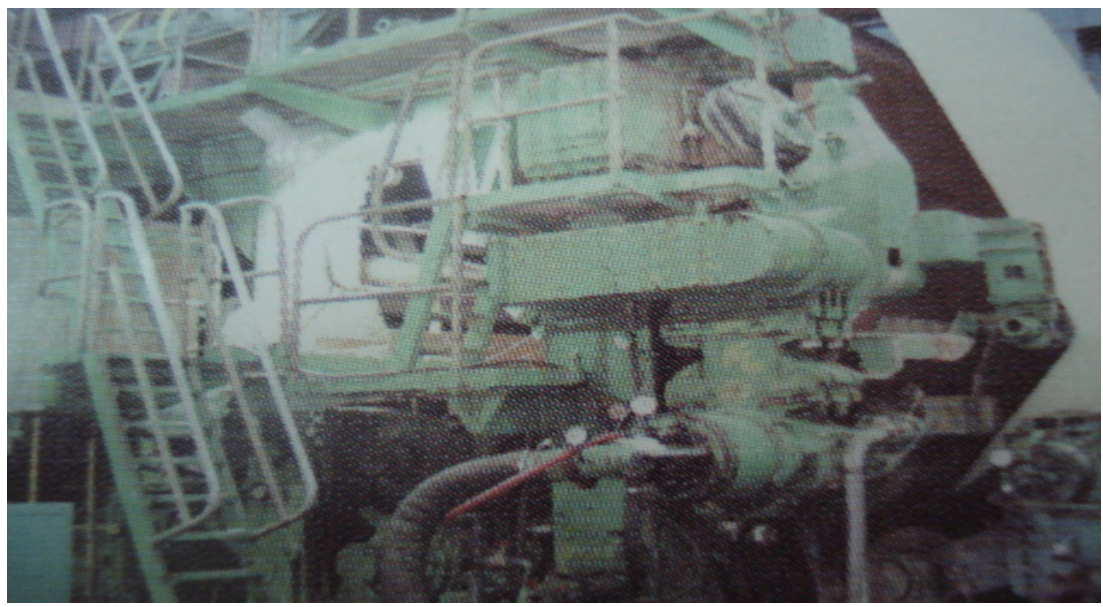

Figure 12. Wet End (Press Section)

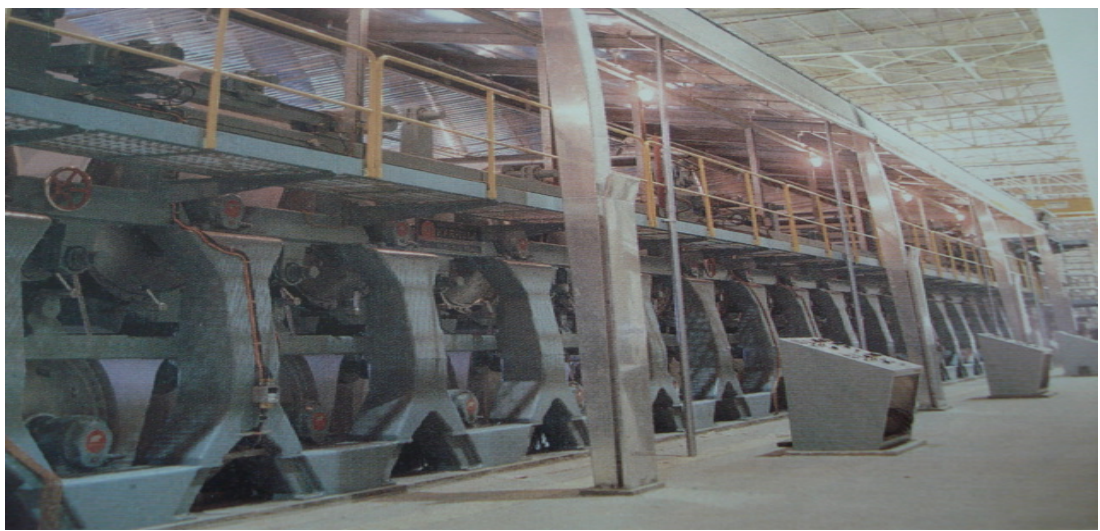

Figure 13. Drying Section

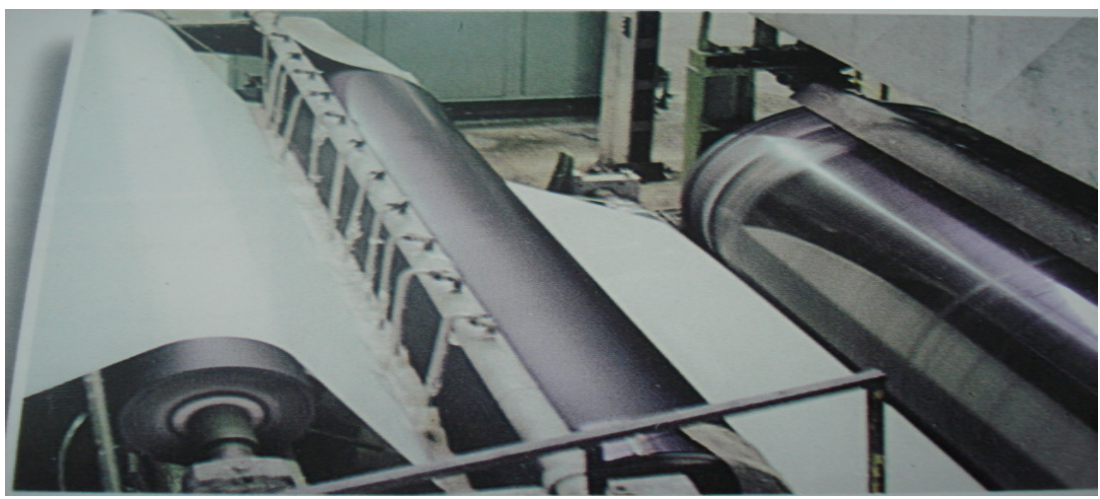

Figure 14. Callevdering Section 


\section{Life Cycle Assessment (LCA)}

LCA is the assessment of the environmental impacts of a given product or process throughout its lifespan [4]. Life cycle of a product include four main stages; production stage, manufacturing stage, use stage and end-of-life stage. The environmental evaluation using the LCA approach is done by applying four steps; defining the goal and scope of the study, establishing a Life Cycle Inventory (LCI), Life Cycle Impact Assessment (LCIA) and finally interpretation of environmental burden associated with the product [5].

\subsection{Goal and scope definition}

The goals of the LCA study are to:

i. Evaluate the environmental performance of paper manufacturing process, and

ii. Identify inputs that have environmental potential from the paper manufacturing.

\subsection{Scopes of the LCA study}

\section{- System boundary}

In this study, the A4 size paper commonly used for writing, printing and copying a document was chosen as an assessing subject in the life cycle assessment. The life cycle of an A4 paper which starts from the raw material extraction stage, production stage, use stage and end-up at the disposal stage. However, the system boundary of the study only focused on the paper production stage (dotted line in Figure 15). In general, the three stages of paper production are: preparation of non-virgin materials, pulp mill and paper mill process [6].

\section{- Functional unit}

The Functional Unit was set as the production of one metric tonne of paper for one year.

\section{- Assumption}

In the LCA study, the following assumptions were made:

There were no wastes or emissions to air and water nor by-products during paper production process and the transportation from each stage is not taken into account because of lack data.

\subsection{Life Cycle Impact Assessment (LCIA) method}

The methodology used to develop this research includes observation, data collection, Site visit and interviews. Several approaches were used for data collection for this study, which are as follow:

Site visit and observation: this was done by visiting the Pars Paper Factory in Iran.

Interviews: some interviews conducted for this research. 


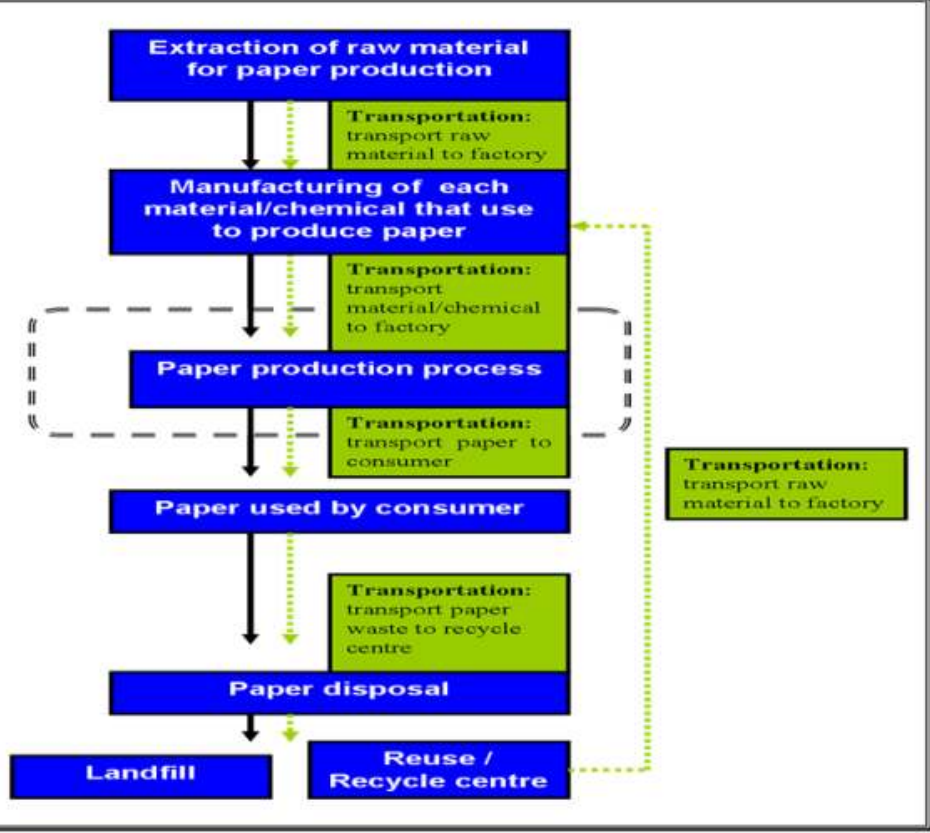

Figure 15. Life Cycle of Paper and System Boundary

Impact assessment is an important step in measuring the environmental impacts in LCA. SimaPro comes with a large number of standard impact assessment methods. In this study, CMLBaseline2000 method was used for Life Cycle Impact Assessment (LCIA). The CMLBaseline2000 provides ten types of impact categories with its unit as shown in Table 1 The emissions inventory data are in terms of the mass released into the environment-such as $1 \mathrm{~kg}$ - per functional unit it also means the impact of a unit mass $(1 \mathrm{~kg})$ of an emission to the environment [7].

\begin{tabular}{|l|l|l|}
\hline No & Impact category & Unit \\
\hline 1 & Abiotic depletion & $\mathrm{Kg} \mathrm{Sb}$ eq \\
\hline 2 & Acidification & $\mathrm{kg} \mathrm{SO} 2 \mathrm{eq}$ \\
\hline 3 & Eutrophication & $\mathrm{Kg} \mathrm{PO}_{4} \mathrm{eq}$ \\
\hline 4 & Global warming & $\mathrm{kg} \mathrm{CO}_{2} \mathrm{eq}$ \\
\hline 5 & Ozone layer depletion & $\mathrm{kg} \mathrm{CFC}-11 \mathrm{eq}$ \\
\hline 6 & Human toxicity & $\mathrm{kg} \mathrm{1,4-DB} \mathrm{eq}$ \\
\hline 7 & Fresh water aquatic ecotoxicity & $\mathrm{kg} \mathrm{1,4-DB} \mathrm{eq}$ \\
\hline 8 & Marine aquatic ecotoxicity & $\mathrm{kg} \mathrm{1,4-DB} \mathrm{eq}$ \\
\hline 9 & Terrestrial ecotoxicity & $\mathrm{kg} \mathrm{1,4-DB} \mathrm{eq}$ \\
\hline 10 & Photochemical oxidation & $\mathrm{kg} \mathrm{C} 2 \mathrm{H}_{4} \mathrm{eq}$ \\
\hline
\end{tabular}

Sb: Antimony CFC: Trichlorofluoromethane DB: Dichlorobenzene

Table 1. Impact Categories and Units 


\section{Results and discussion}

CMLBaseline2000 was used to analyze the potential environmental impact using Simapro 7.0 database. The graph is scaled to $100 \%$ per impact category, in order to allow the description of widely dispersed values per impact category in one diagram (Figure 16). Colour difference of the graph is representing the different types of input. The negative value of the impact means benefit to the environmental. The impact value for each impact was contributed from inputs that were used during the paper making process. In this factory, there were 12 types of inputs involved in the process and had been analyzed. They were; Bagasse (farmed tree 1), Kraft (farmed tree 2), Electricity, Heavy fuel oil (Mazut), Water, Sodium hydroxide $(\mathrm{NaOH})$, Aluminum sulphate $\left(\mathrm{Al}_{2}\left(\mathrm{SO}_{4}\right)_{3}\right)$, Optical Brightness Agent (OBA), Chlorine (Cl). Clay, Corn Starch and Resin.

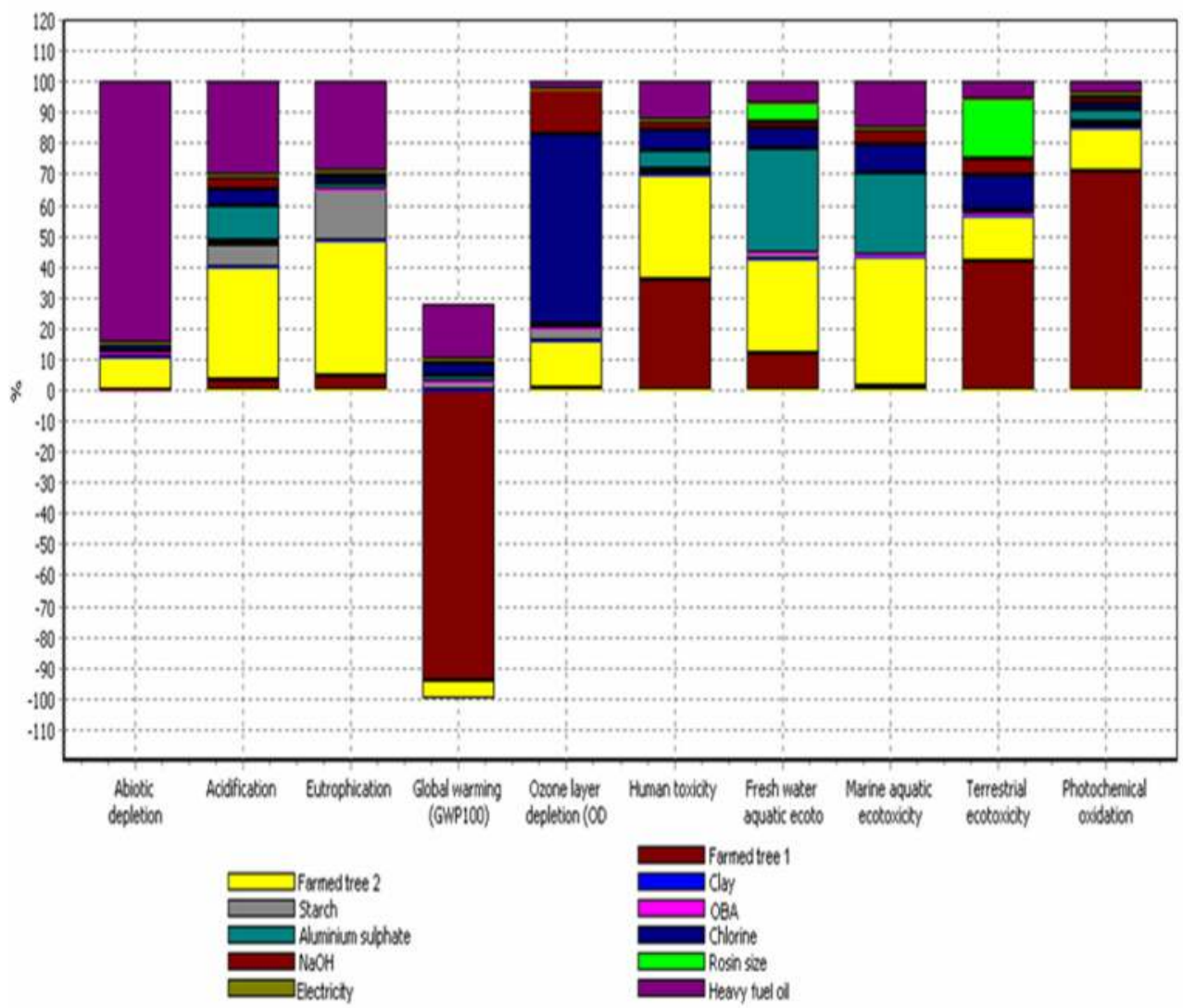

Figure 16. Impacts of paper production process from all inputs 


\subsection{Abiotic depletion}

Inputs that Cause Abiotic Depletion Impact shown in Figure 17. From the total, mazut (fuel oil) contribute the highest impact value of $85 \%$ followed by kraft with $11 \%$, of the total impact. The resin, bagasse, OBA (Optical Brightness Agent), $\mathrm{NaOH}$, corn starch and Aluminum sulphate make up smaller impacts in a range of $0.1-2.0 \%$. Clay and electricity contribute very little impact which are $2.90 \times 10^{-3} \mathrm{~kg}$ Sb eq and $2.91 \times 10^{-5} \mathrm{~kg}$ Sb eq, respectively and this is the reason why these two inputs give almost no impact value. It was identified that for abiotic depletion, mazut is the main input that contributes the highest impact value while electricity was the lowest. In the paper production process, mazut is used as an energy source for heating and steam-raising for furnaces, kilns and boilers. Mazut is a brownishblack petroleum fraction consisting largely of distillation residues from asphaltic-type crude oils, with a relative density of about 0.95 . This means coal contains the highest amount of carbon per unit of energy, so it emits more greenhouse gases than the other fossil fuels [8]. The consumption of hydroelectric power will reduce environmental degradation because of renewable sources [9]. Electricity derived from fossil fuels can increase global greenhouse gases (GHG) while hydroelectricity or nuclear electricity may not increase the GHG emissions $[8,10]$.

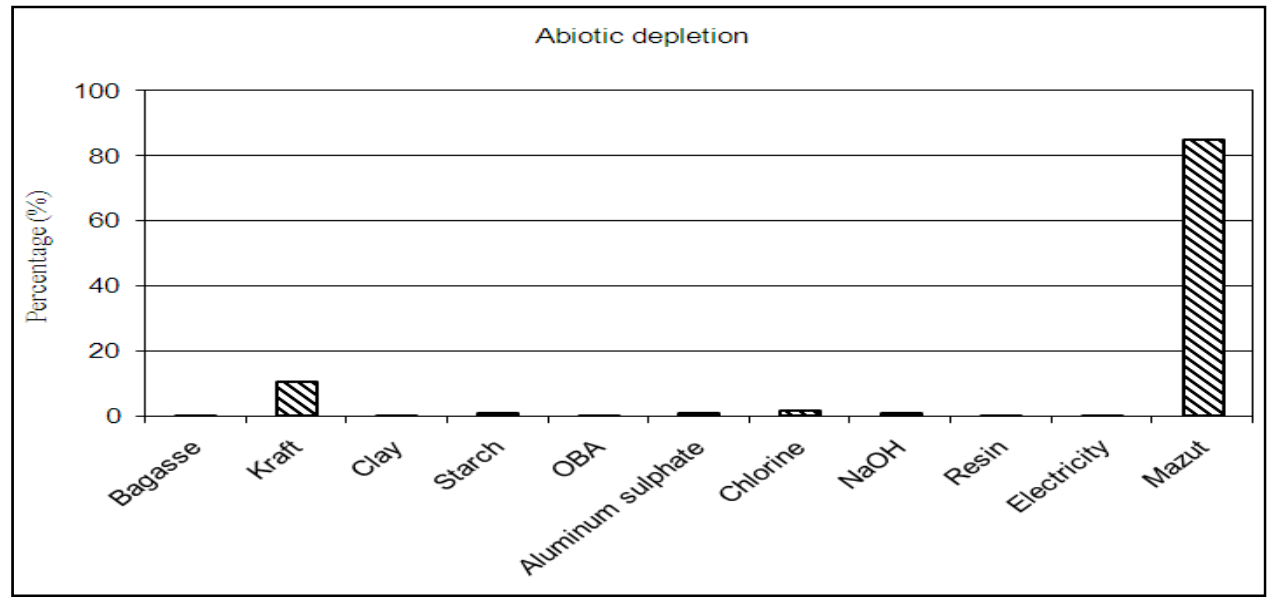

Figure 17. Inputs Cause Abiotic Depletion Impacts

\subsection{Acidification}

Acidic gases such as sulfur dioxide, nitrogen oxides (released during the burning of fossil fuels) contribute to the acidification of the soil and fresh water ecosystem. The category indicator for acidification was measured in kilograms of sulfur dioxide equivalent $\left(\mathrm{Kg} \mathrm{SO}_{2}\right.$ eq). Weigard, (2001) indicated that $\mathrm{N}_{2} \mathrm{O}$ is produced naturally through human activities such as the burning of fossil fuels, deforestation, land-use changes and some industrial processes (Figure 18). 


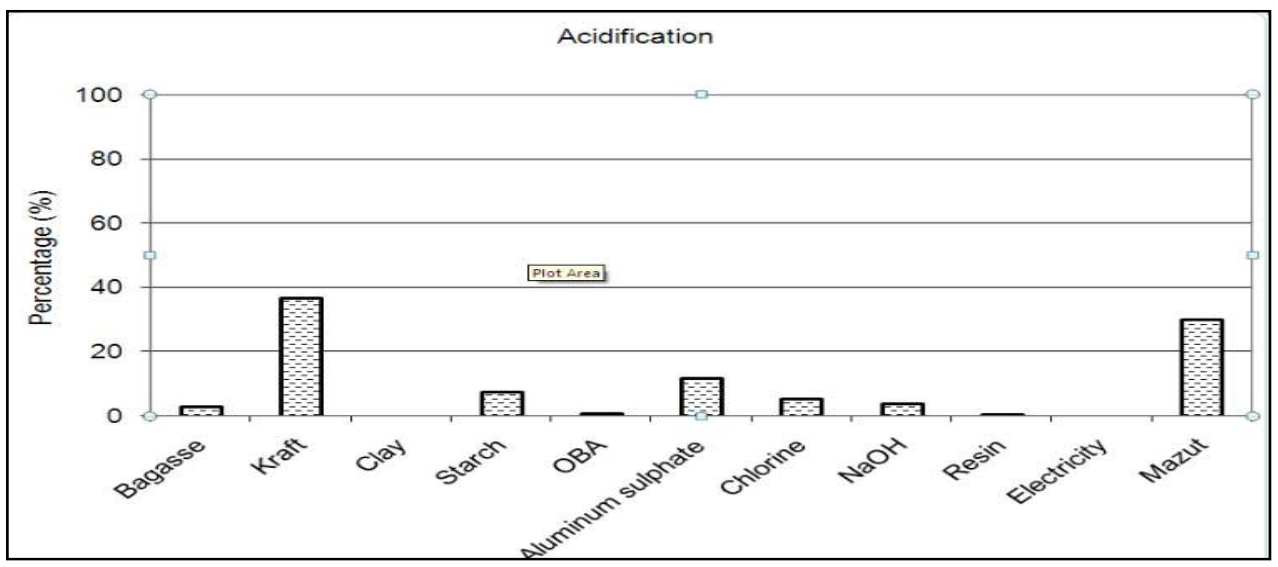

Figure 18. Inputs for Acidification Impact

\subsection{Eutrophication}

As it shown in Figure 19, Kraft gives the highest impact (44\%) in eutrophication followed by mazut $(29 \%)$, starch $(16 \%)$, bagasse $(5 \%)$, Aluminum sulphate $(2 \%)$, chlorine $(2 \%)$, resin $(1 \%), \mathrm{NaOH}(1 \%), \mathrm{OBA}(1 \%)$, clay $(0.3 \%)$ and electricity $(0.0001 \%)$. The enrichment of soil and water by nutrients is measured by the EP (Eutrophication) impact category. An increased EP could lead to algal blooms in lakes with reduction in sunlight penetration and other adverse consequences, and similar undesirable effects on soil. Release of nitrates and phosphates continuously to fresh water and marine water can cause increased nutrient buildup. During the combustion of fossil fuels and fuel production high $\mathrm{NO}_{\mathrm{x}}$ is produced $[11,12]$. This can result in accumulation of nitrates, phosphates and dissolved oxygen content [13].

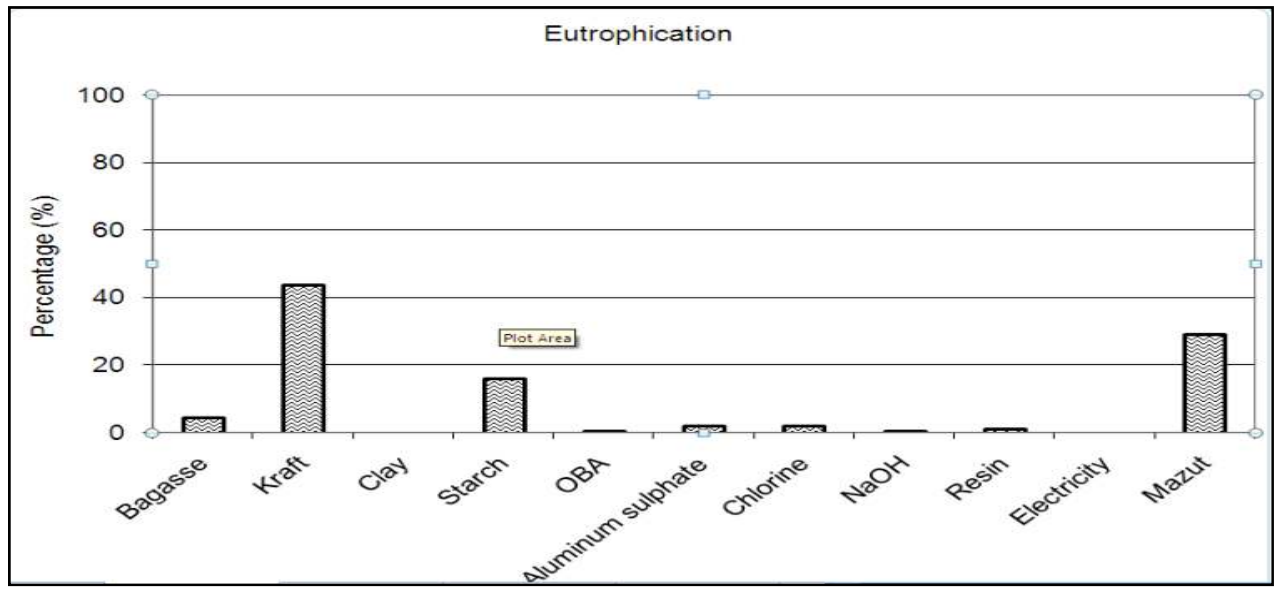

Figure 19. Inputs for Eutriphication Impact 


\subsection{Global warming}

Impact to global warming was measured in $\mathrm{kg} \mathrm{CO}_{2}$ equivalent. Figure 20 shows the impact value to global warming from each input. Bagasse gave a negative impact value which was $130 \%$ while kraft gave value by $-9 \%$. Other inputs such as clay, starch, OBA, aluminum sulphate, chlorine, resin, electricity and $\mathrm{NaOH}$ gave positive impacts which are $0.02 \%, 3 \%$, $0.5 \%, 3 \%, 5 \%, 2 \%, 0.1 \%, 0.002 \%$ and $25 \%$, respectively, of the total impact. For global warming impact, mazut contributed the highest impact value $(25 \%)$ and bagasse the lowest $(-130 \%)$. Weigard, (2001) illustrated that burning fossil fuels can release 6.2 (GtC) into the atmosphere each year. His study was done using LCA for quantification of greenhouse gases at Visy industries. Based on his research, Weigard, (2001) believes that changing landuse (eg. deforestation) results in increased emissions of carbon. Likewise, the results of this study show that using bagasse as a renewable raw material for paper production could lead to less deforestation because bagasse has a negative impact on the environment. The negative value of the impact indicates benefits to the environmental

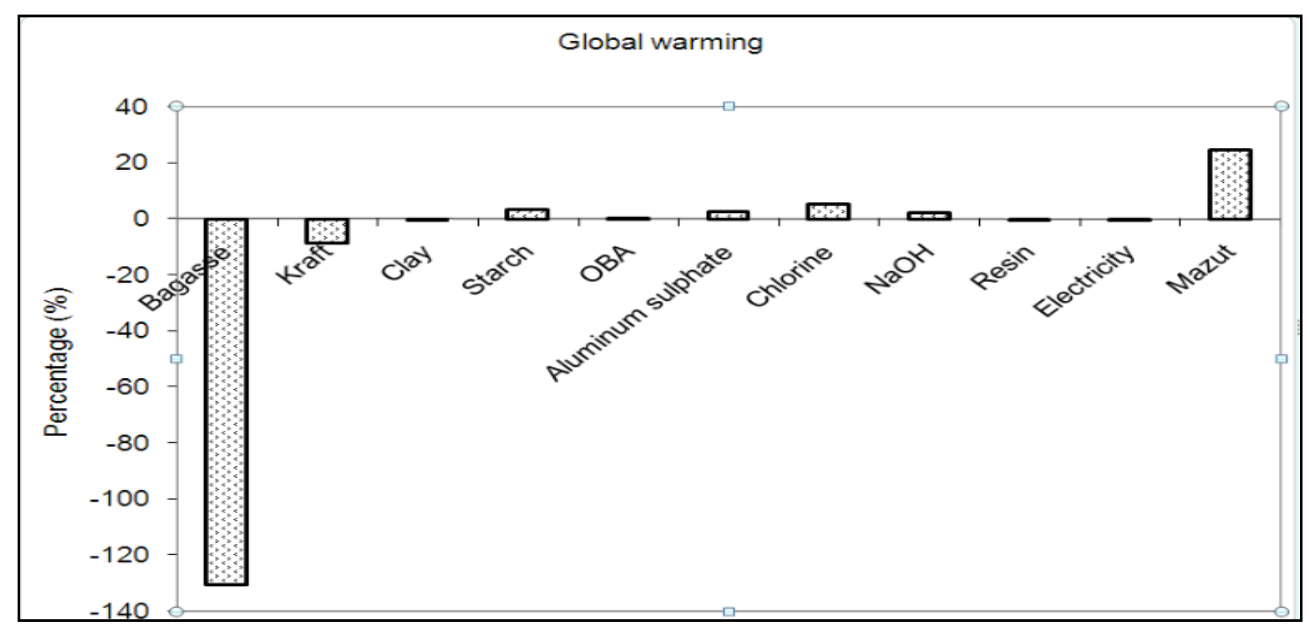

Figure 20. Inputs for Global Warming Impact

\subsection{Ozone layer depletion}

Ozone layer depletion was measured as CFC-11 equivalent. Inputs that contributed to this impact are shown in Figure 21. Chlorine contributed the major impact value with $62 \%$ and electricity the lowest at $\left(7.8 \times 10^{-05} \%\right)$. Kraft was the second major contributor $(16 \%)$ and $\mathrm{NaOH}$ was the third (14\%). Others made up a small range of impacts which was less than $5 \%$ each; starch $(4 \%)$, mazut $(2 \%)$, aluminum sulphate $(1 \%)$, OBA $(0.4 \%)$, bagasse $(0.4 \%)$, resin $(0.2 \%)$ and clay $(0.01 \%)$.

Before the 1980s and early 1990s, free chlorine was used to bleach paper; however, nowadays, the use of free chlorine has ceased and chlorine-dioxide or other means of bleaching such as ozone which have taken over [14].Chlorofluorocarbons (eg. CFC-11 and 
CFC-12) were first manufactured in the 1930's but were not present in the atmosphere in any appreciable quantity before 1950. Up until the 1990's, they were widely used as propellants, refrigerants and foaming agents. They act as a GHG in the troposphere but also damage the ozone layer in the stratosphere. The study shows that man-made chemicals can cause ozone layer depletion [8].

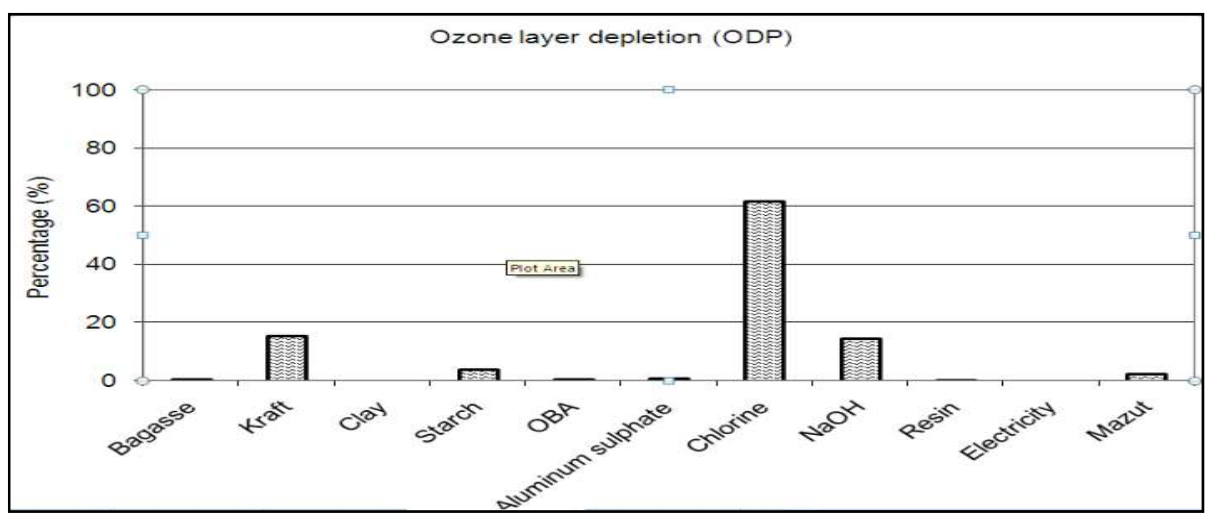

Figure 21. Inputs for Ozone Layer Depletion

\subsection{Toxicity}

The toxicity impact was measured as 1, 4-DichloroBenzene equivalents/ $\mathrm{kg}$ emission $(\mathrm{Kg} 1,4-$ DB eq). In the CML2BaseLine2000 method for LCIA, toxicity to human environment, fresh water, marine and terrestrial ecosystem were considered. Figure 22 explains the toxicity impacts of the various materials/elements. From the total impact, kraft contributed the highest impact of about $42 \%$. Aluminum sulphate was in second place with $26 \%$ followed by mazut $(15 \%)$, chlorine $(10 \%), \mathrm{NaOH}(4 \%)$, bagasse $(1 \%)$, starch $(1 \%)$, resin $(1 \%)$, OBA $(0.2 \%)$, clay $(0.02 \%)$ and electricity $(0.0005 \%)$.

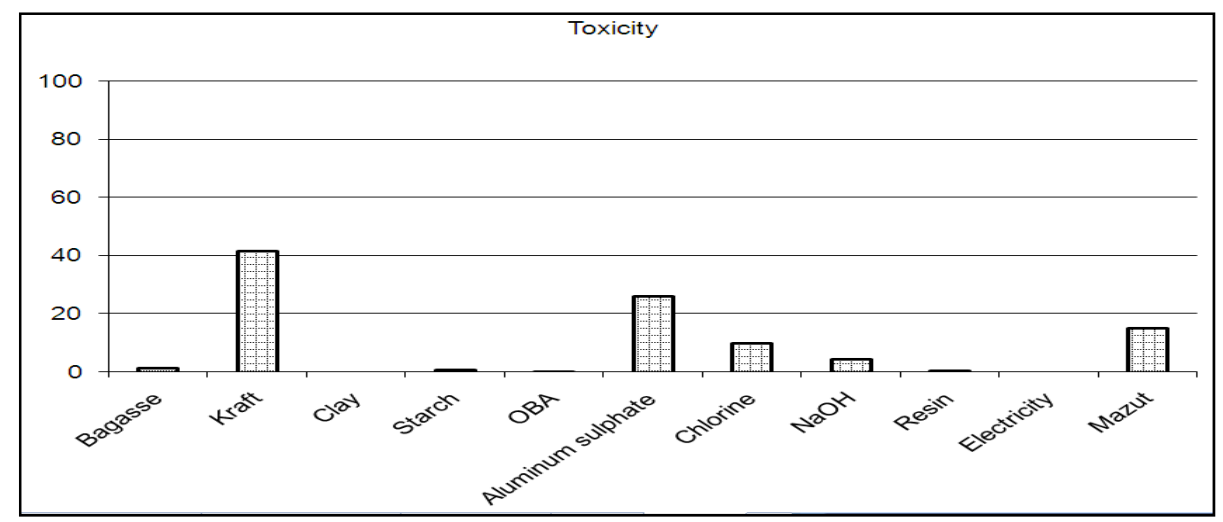

Figure 22. Inputs for Human, Freshwater, Marine and terrestrial ecotoxicity Impacts 


\subsection{PhotoChemical oxidation}

Figure 23 shows the impact value of each input for photochemical oxidation. Bagasse gave the highest impact value in photochemical oxidation with $71 \%$. Kraft contributed $14 \%$, aluminum sulphate and mazut $4 \%$ each which chlorine and resin contributed $2 \%$ each, starch and $\mathrm{NaOH} 1 \%$ each. OBA, clay and electricity were at the lower and of the range at $0.2 \%, 0.008 \%$ and $0.001 \%$ respectively.

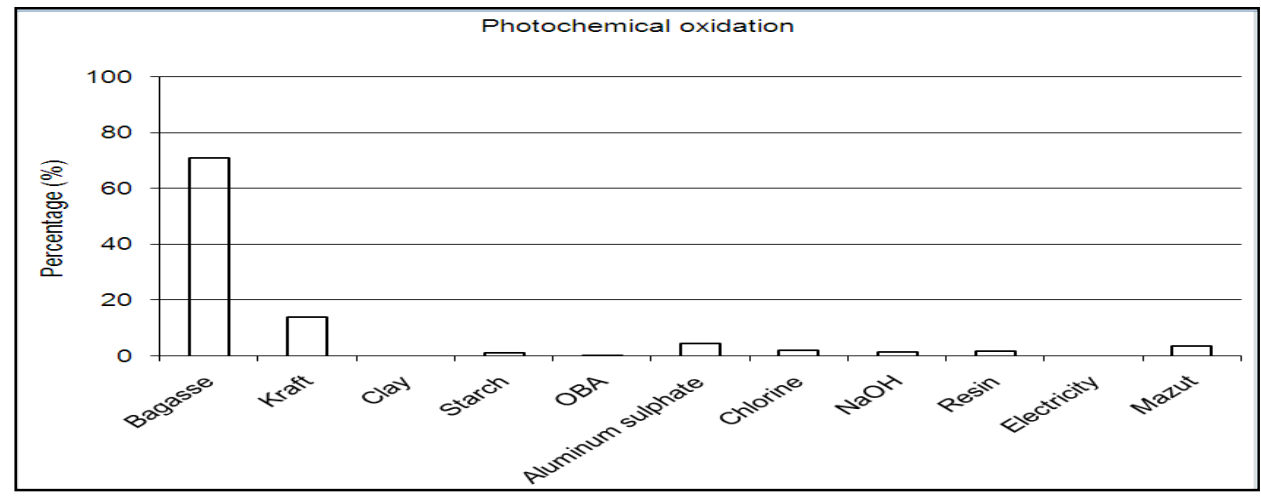

Figure 23. Inputs for Photochemecal Oxidation Impacts

\section{Conclusion}

Based on the above study, following conclusions are drawn:

1. Nuclear energy, hydroelectricity or even using pith as a source of friendly energy should be used in place of Mazut for paper making.

2. More environmentally friendly materials for bleaching should be used against chlorine.

3. Paper recycling is to be utilized in place of Kraft to reduce the amount of impact of Kraft on.

\section{Author details}

Sotoodehnia Poopak

Institute of Biological Science, Faculty of Science, University of Malaya, Kuala Lumpur, Malaysia

Amiri Roodan Reza

Department of Knowledge Management, Faculty of Creative Multimedia, Cyberjaya, Malaysia

\section{References}

[1] Honnold, V (2009).Developments in The Sourcing of Raw Materials for the Production of Paper. United States International Trade Commission. J of Int Commerce and Economics.

${ }^{*}$ Corresponding Author 
[2] Malaysian Newsprint Industries (2007). Paper Recycling Report. http://www.newsprint.com.my.

[3] WasteCap, 2008. WasteCap of Massachusetts.68 Hopkinton Road/ Westboro/MA 01581, March 2008. http://www.WasteCap.Org/WasteCap/Commodities/Paper/Paper.htm.

[4] Curran M A (2006). Life Cycle Assessment Principal and Practice, National Risk Management Research Laboratory, U.S Environmental Protection Agency, Cincinnati, Ohio 45268.1-15.

[5] Murphy R(2004).Green Composites. Imperial College, London, United Kingdom.23-26.

[6] Dias A C, Arroja L, Capela I(2007). Life Cycle Assessment of Printing and Writing Paper Produced in Portugal. Int J of LCA, 12(7).521-528.

[7] Pennington D W, Potting J, Finnveden G, Lindeijer E, Jolliet O, Rydberg T, Rebitzer(2004). Life Cycle Assessment Part 2: Current Impact Assessment Practice. J of Environment Int, 30,721-739.

[8] Wiegard Jean (2001). Qualification of GreenHouse Gases at Visy Industries Using Life Cycle Assessment. M Tech Thesis, Swinburne University of Technology, Australia.

[9] Fress N, Hansen M S,Ottosen L M, Toenning K, Wenzel H(2005). Update of the Knowledge Basis on the Environmental Aspects of Paper and Cardboard , Environmental Project No 1057, Danish Environmental Protection Agency , Copenhagen, Denmark.

[10] Elliason, B (2000). Energy in the $21^{\text {st }}$ Century , The Role of GHG Control Technologies, Paper Presented at the $5^{\text {th }}$ International Conference on Greenhouse Gas Control Technologies (GHGT-5)/August, Cairns.

[11] Eriksson E, Gilespie A R, Gustavsson L, Langvall O, Olsson M, Sathre R (2007). Integrated Carbon Analysis of Forest Management Practices and Wood Substitution. J of Forest Resource, 36.671-681.

[12] Ally Jamie, Pryor T (2007). Life Cycle Assessment of Diesel, Natural Gas and Hydrogen Fuel Cell Bus Transportation System. J. of Power Sources, 170. 401-411.

[13] Gordon G (2003). Interior Lighting for Designers. New Jersey: John Wiley and Sons Inc,197-198.

[14] Villanueva A, Wenzel H (2007). Paper Waste-Recycling, Incineration or Landfilling? A Review of Existing Life Cycle Assessments. J of Waste Management ,27,29-46. 